\title{
Combining cover cropping with deficit irrigation in a Mediterranean low vigor vineyard
}

\author{
Carlos M. Lopes ${ }^{\mathrm{a}, *}$, Tiago P. Santos ${ }^{\mathrm{b}}$, Ana Monteiro ${ }^{\mathrm{a}}$, M. Lucília Rodrigues ${ }^{\mathrm{a}}$, \\ Joaquim M. Costa ${ }^{a}$, M. Manuela Chaves ${ }^{\mathrm{a}, \mathrm{b}}$ \\ ${ }^{a}$ Centro de Botânica Aplicada à Agricultura, Instituto Superior de Agronomia, Universidade Técnica de Lisboa, Tapada da Ajuda, $1349-017$ Lisboa, Portugal \\ ${ }^{\mathrm{b}}$ Instituto de Tecnologia Química e Biológica, Universidade Nova de Lisboa, Oeiras, Portugal
}

\section{A R T I C L E I N F O}

\section{Article history:}

Received 14 March 2011

Received in revised form 21 April 2011

Accepted 28 April 2011

\section{Keywords:}

Cover cropping

Grapevine

Partial rootzone drying

Deficit irrigation

Soil tillage

\begin{abstract}
A B S T R A C T
The aim of this research was to test the effects of vineyard soil management practices combined with deficit irrigation strategies on the performance of the grapevine (Vitisvinifera L.) red variety Tempranillo. Two soil management practices (soil tillage - ST and permanent resident vegetation - RV) were combined with three deficit irrigation treatments (regulated deficit irrigation - RDI, partial rootzone drying - PRD and conventional sustained deficit irrigation - DI) during two growing cycles. Compared to ST, RV reduced soil water content during spring, inducing a significant reduction in vine vegetative growth, yield and must titratable acidity. The effects of irrigation treatments were not much pronounced. Only in the second season RDI showed a significant reduction on vine vegetative growth, yield and must titratable acidity as compared to PRD and DI whose results were similar to one another.

In a dry area such as ours and a low vigor vineyard, the combination of resident vegetation with deficit irrigation treatments should be carefully considered as it can reduce yield without any benefits to grape quality. In this site the conventional deficit irrigation should be preferred to RDI and PRD as it is technically the simplest deficit irrigation strategy and has enabled an efficient control of vegetative growth without negative impact on yield and berry composition as compared to the other irrigation treatments.
\end{abstract}

() 2011 Elsevier B.V. All rights reserved.

\section{Introduction}

Considering the predicted scenarios of climate change over the next decades (IPCC, 2007), Mediterranean vineyards will face a substantial shift in precipitation patterns (higher winter rains and dry summers). This will bring about the need for the adaptation of cultural practices in order to mitigate the negative effects of those changes. One possible adaptation measure is the use of irrigation combined with cover crops. Cover crops will prevent erosion and increase infiltration rates during the rainy period, while irrigation will compensate for the water used by cover crops in the spring, thereby preventing an excessive competition with the vines (Schultz, 2007).

Vineyard cover cropping is a floor management tool widely used in the world's winegrowing regions, mainly in areas with

Abbreviations: ASW, available soil water; DI, deficit irrigation; DWU, daily water use; $\mathrm{ET}_{\mathrm{c}}$, crop evapotranspiration; $\mathrm{ET}_{0}$, reference evapotranspiration; $\psi_{\text {pd }}$, predawn leaf water potential; FTSW, fraction of transpirable soil water; PPFD, incident photosynthetic photon flux density; PRD, partial rootzone drying; RDI, regulated deficit irrigation; RV, resident vegetation; ST, soil tillage; SWD, soil water depletion; TTSW, total transpirable soil water; TWU, total water use.

* Corresponding author. Tel.: +351 21 3653450; fax: +351213653289.

E-mail address: carlosmlopes@isa.utl.pt (C.M. Lopes). summer rainfall or with irrigation. The benefits of using cover crops range from environmental protection (Folorunso et al., 1992; Gulick et al., 1994; Morlat and Jacquet, 2003; Ingels et al., 2005) to vineyard management, including control of vigor and grape quality (Geoffrion, 1999; Maigre and Aerny, 2001; Lopes et al., 2008). Despite those potential benefits, the adoption of cover crops in Mediterranean non-irrigated vineyards has been limited by the concern of excessive water competition between the swards and vines. Indeed, in non-irrigated vineyards located in areas of low summer rainfall and high evaporative demand, improperly selected or managed cover crops may induce a strong competition with vines for water (Prichard, 1998; Lopes et al., 2004) and nutrients (Hirschfelt, 1998; Geoffrion, 1999; Celette et al., 2008). This may lead to severe vine water stress and consequently to negative effects on growth, yield and berry quality (Williams and Matthews, 1990). However, the additional water used by the cover crops can be advantageous in some "terroirs" like, for example, in Mediterranean irrigated vineyards where favourable temperatures in the spring combined with high soil water availability can induce high vegetative growth rates, enabling a fast grapevine canopy establishment. This may lead to a dense canopy, creating unbalanced vines with unfavourable microclimate at the cluster zone, which can increase the risk of fungal attacks and be deleterious for berry ripening (English et al., 1990; Smart and Robinson, 1991). Furthermore, 
these vines need a more intensive canopy management, like shoot trimming and defoliation, thus increasing vineyard management costs. Under those situations the use of cover cropping between rows that will withdraw water from the profile can be advantageous for generating a mild water stress and therefore enable an early stop of vegetative growth and a consequent reduction of vine vigor and canopy density (Caspari et al., 1997; Geoffrion, 2000; Afonso et al., 2003; Lopes et al., 2008). The control of canopy development can also reduce water consumption during ripening and improve water use efficiency (Linares et al., 2007; Monteiro and Lopes, 2007).

The lower competition between vegetative and reproductive growth, combined with the higher cluster exposure induced by a lower canopy density, can enable an improved fruit colour and higher anthocyanin concentrations in red grape varieties (Dokoozlian and Kliewer, 1996; Keller and Hrazdina, 1998; Spayd et al., 2002). The reduction in berry set caused by the water competition can also be an advantage if lower yields are needed for high quality wines (Linares et al., 2007).

In irrigated vineyards the concern of excessive water competition between the cover crop and vine is discarded by the possibility to supplement the vines with irrigation water. In dry viticultural regions deficit irrigation strategies such as regulated deficit irrigation (RDI) and partial rootzone drying (PRD) have been successfully adopted as management tools to control vine vegetative growth and improve fruit composition, while enhancing plant water use efficiency (Stoll et al., 2000; Dry et al., 2001; Santos et al., 2003; Loveys et al., 2004). RDI is one of the most used irrigation strategies in grapevines with the aim to apply a controlled water deficit over a limited period, for example, after berry set and up to veraison, aiming to manipulate grapevine vegetative and reproductive growth (McCarthy, 1997; Battilani, 2000; Wample and Smithyman, 2002; Keller et al., 2008). In red grape varieties an effect on fruit composition is also expected mainly by the indirect effects on berry size and cluster exposure (Dry et al., 2001; McCarthy et al., 2002). A short period of water stress immediately after berry set, by restricting cell division and enlargement, can induce a reduction in berry size that may improve disease resistance and wine quality in red grape varieties as smaller berries would result in a less compact bunch and in a higher skin/flesh ratio (Wample and Smithyman, 2002). Additionally, a short period of water stress after veraison may enhance anthocyanin accumulation (Dry et al., 2001). However, RDI has some implementation difficulties. There is the need for a good plant and soil water monitoring system in order to avoid the risk of severe water stress at periods of extreme high temperature events (Goodwin, 2002). Also, the possibility of implementing a short period of water stress immediately after berry set is strongly dependent of the soil water availability at flowering time, which depends on the amount of winter and early spring rains and on the water used during spring. As in "Alentejo" winegrowing region, South Portugal, the storage of winter and spring rain can induce high levels of rootzone total available water at flowering time, the use of cover crops combined with RDI can be a valuable tool to enhance the effects of RDI. Under such circumstances, the additional water used by the cover crops in the spring (Pellegrino et al., 2004; Monteiro and Lopes, 2007) can be the only way to remove the winter rain from the rootzone enabling a better control of vegetative growth and an adequate berry set.

Partial rootzone drying was developed in recent years to control plant growth and transpiration, avoiding severe water stress periods that can occur in RDI (Dry and Loveys, 1998; Loveys et al., 2000). With the PRD technique part of the grapevine root system is slowly dried, while the remaining roots are exposed to wet soil. This enables the roots of the watered side to maintain a favourable plant water status, while dehydrating roots produce chemical signals that are then transported to the shoots via the xylem and will hypothetically control vegetative growth and stomatal aperture (Dodd et al., 1996; Dry et al., 1996; Stoll et al., 2000). Compared to standard conventional irrigation techniques one important advantage of PRD is a better control of vegetative growth reported under several circumstances (Dry and Loveys, 1998; Loveys et al., 2000), providing an adequate exposure of the clusters to sunlight and the possibility of saving water without having any detrimental impact on the yield and grape quality (Santos et al., 2003, 2005, 2007).

Despite the increasing use of vineyard irrigation and cover cropping very little work has been made to study the interaction between cover crops and deficit irrigation strategies. The aim of the present research was to compare the effects of two soil management practices combined with three deficit irrigation strategies on weed dynamics, soil water status, vine vegetative growth and its consequences on yield and berry composition of the red variety Aragonez (syn. Tempranillo) grown in Mediterranean conditions.

\section{Materials and methods}

\subsection{Site characteristics and experimental set-up}

This research was conducted during the 2005 and 2006 growing seasons in a commercial vineyard, located at Estremoz, Alentejo winegrowing region, Southern Portugal (lat. $38^{\circ} 51^{\prime} \mathrm{N}$; long. $7^{\circ} 33^{\prime}$ W). The climate is of the Mediterranean type, with hot and dry summers and mild rainy winters. The soil is derived from schist with a variable depth $(1.0-1.5 \mathrm{~m})$. Soil horizons present a silty clay loam texture with the following average characteristics: clay $34.2 \%$; silt 30.4\%; sand 35.4\%; organic matter 2.0\%; $\mathrm{pH}\left(\mathrm{H}_{2} \mathrm{O}\right) 7.1$. The total soil available water up to $1.0 \mathrm{~m}$ depth was $124.2 \mathrm{~mm}$ calculated as the difference between field capacity and permanent wilting point determined by gravimetric method.

The six-year-old grapevines of the red variety Aragonez (syn. Tempranillo) were grafted to 1103 Paulsen rootstock and spaced $1.0 \mathrm{~m}$ within and $2.5 \mathrm{~m}$ between rows. Vines were trained on a vertical shoot positioning with a pair of movable wires and spur-pruned on a bilateral Royat Cordon system. All vines were uniformly pruned to 12-14 nodes per vine. Before setting up the experiment floor management had been resident vegetation since the third year after plantation. Standard cultural practices in the region were applied to all treatments. Shoots were trimmed at about $1.2 \mathrm{~m}$ of length ( $0.25 \mathrm{~m}$ above the higher wire), one or two times between bloom and berry pea size. No chemical fertilization was applied during the period of the experiment.

The new soil management practice (soil tillage) was set up during the spring of 2004, one year before the beginning of data collection, in order to allow the vines to adapt to the new regime. The experimental layout was a split-plot design with two soil management treatments (main-plot) combined with three drip irrigation treatments (sub-plot) with four replications per treatment. The experimental plot was first divided in two main-plots of nine adjacent rows each for the assignment of the soil management treatments. Each main-plot was further divided in three sub-plots for the assignment of the irrigation treatments. The elemental plot comprises three adjacent rows (two buffer rows and a central one for data collection) of twenty vines each.

The soil management treatments were soil tillage between rows (ST) and permanent resident vegetation cover between rows (RV). The ST treatment included vegetation mowing in the first week of February (a common operation that aims to shred vine winter pruning) and soil cultivation with a spading machine in spring (end of April) to incorporate the vegetation into the soil. In the RV treatment the vegetation was mowed by a flail mower twice a year, namely before vine budburst and by the end of April, to a height of $10-15 \mathrm{~cm}$. 
The drip irrigation treatments were: RDI; PRD and conventional sustained deficit irrigation (DI - control). Drip irrigation lines were positioned in the centre of the row and consisted of pressure compensating $2.5 \mathrm{~L} / \mathrm{h}$ emitters at $1.0 \mathrm{~m}$ spacing (one per vine positioned between two adjacent vines) except for PRD which had two drip irrigation lines with emitters spaced $2.0 \mathrm{~m}$. Those two irrigation lines of PRD were independently controlled and positioned in order to have always one emitter between two adjacent vines and allow alternated water supply to each side of the root system, which was done every two weeks. Each irrigated treatment was independently controlled and equipped with a time clock valve assembly to control water delivery. In order to mimic the standard deficit irrigation practiced in the region for high quality red wines, the onset of irrigation was done after flowering. PRD and DI irrigation started at 8th June 2005 and at 29th May 2006 and was stopped by the end of August in both seasons. In RDI irrigation started at 8th June 2005 and 19th June 2006 and was withheld during the last three weeks of the ripening period of both seasons.

Watering was applied according to the crop evapotranspiration $\left(\mathrm{ET}_{\mathrm{C}}\right)$ and soil water content. $\mathrm{ET}_{\mathrm{c}}$ was estimated from the reference evapotranspiration $\left(\mathrm{ET}_{0}\right)$, which was obtained in an automatic weather station located within the experimental vineyard, using the crop coefficients proposed by Allen et al. (1998). During irrigation, on all treatments, the average fraction of $\mathrm{ET}_{\mathrm{c}}$ applied was $c a$ 0.4 before veraison and $c a 0.3$ after veraison. Frequency of water applications was the same for all irrigated treatments and varied from 2 to 5 days. The total amount of water supplied to PRD and DI plants was 135.6 and $133.4 \mathrm{~mm}$ in 2005 and 2006 respectively, while on RDI the supply was $115.7 \mathrm{~mm}$ in 2005 and $85.9 \mathrm{~mm}$ in 2006.

In all treatments a $0.8 \mathrm{~m}$-wide herbicide strip was achieved beneath the vines, thereby allowing a width of the planter of about $1.7 \mathrm{~m}$. A single application, just before bud break, of the foliage herbicide $1.8 \mathrm{~g}$ a.i. ha ${ }^{-1}$ glyphosate (ROUNDUP $360^{\circledR}$, Monsanto) was made.

\subsection{Vegetation assessments}

Vegetation above-ground biomass was periodically assessed from the end of January until September. Shoots from each species were harvested by cutting plants at soil surface level inside six randomized $0.5 \mathrm{~m}^{2}$ areas per elemental plot and percentage of soil cover was assessed visually $(0=$ no vegetation; $100=$ total soil coverage) by two independent observers. Dry matter per species was recorded. Plant species from the survey carried out at the end of April were grouped according to annual grass species, annual broad-leaved species, perennial grass species and perennial broad-leaved species. Biomass values were transformed on relative biomass values for each species, using the method described by Derksen et al. (1993) and Streit et al. (2003), but applied to species biomass instead of species density.

\subsection{Soil and vine water status}

Soil water content was monitored using a capacitance probe (Diviner $2000^{\circledR}$; Sentek Sensor Technologies, South Australia). One or two (PRD, one each side of the vine) access tubes per plot in a total of 8 (DI and RDI) or 16 (PRD) per irrigation treatment and 16 per soil management treatment were placed under the rows at mid-distance between two adjacent vines near the emitters. Readings were taken periodically between budburst and harvest at increments of $0.1 \mathrm{~m}$ from the soil surface to a depth of $1.0 \mathrm{~m}$. Supplementary measurements were made at the end of summer, before the first rains, and during the winter of 2006 to determine the minimum and maximum soil moisture profiles required to calculate total vine transpirable soil water (TTSW). TTSW was estimated for each access tube as the difference between soil water content at field capacity and minimum soil water content. At a given date the available soil water (ASW) was calculated as the difference between soil water content on the day of measurements and the soil water content minimum. The fraction of transpirable soil water (FTSW) was calculated as the ratio of ASW to TTSW (Pellegrino et al., 2004).

Vine predawn leaf water potential was periodically measured between vine flowering (end of May) and harvest (first week of September). Measurements were carried out on an adult leaf from six replicate plants from each treatment within the two central plots (three leaves per plot), using a pressure chamber (Model 1000; PMS instrument Co., Corvallis, OR, USA). With the exception of the first measurement all measurements were carried out at the end of an irrigation cycle.

\subsection{Vine vegetative growth, canopy density and leaf nitrogen content}

The length of a representative sample of 120 shoots per soil treatment was recorded at berry set. Leaf area per shoot was assessed periodically in a sample of 20 representative shoots per irrigation treatment (60 per soil management treatment) from flowering onwards in a non-destructive way, using the methodologies proposed by Lopes and Pinto (2005). Leaf area per plant was calculated by multiplying the average leaf area per shoot by the average shoot number per plot. In winter, shoot number and fresh pruning weight per vine were also recorded.

Canopy density was assessed by point quadrat analysis (Smart and Robinson, 1991). Light at the cluster zone was measured at mid-ripening in sunny days at midday using a Sunflek Ceptometer (model SF-40, Delta T Devices Ltd.). The values of incident photosynthetic photon flux density (PPFD) were expressed in percentage of a reference PPFD, measured over the canopy top.

The nitrogen concentration of leaf blades was determined in 2006, at flowering, on a sample of eight leaves per elemental plot (a total of 96 leaves per soil management treatment). Leaves were detached from the basal part of the shoot opposite a bunch. Total nitrogen content was measured by Kjeldahl method (Horneck and Miller, 1998) using leaf blade material that had been dried and powdered.

\subsection{Yield and berry composition}

At harvest a sample of 200 berries per plot was collected and weighed and the juice was analyzed for $\mathrm{pH}$, soluble solids ( ${ }^{\circ}$ Brix), determined by refractometry, and titratable acidity by titration with $\mathrm{NaOH}$ (OIV, 1990). Total phenols were determined by spectrophotometry, measuring ultraviolet absorption at $280 \mathrm{~nm}$ and berry skin anthocyanins were measured using the sodium bisulphite discoloration method (Ribereau-Gayon et al., 1972). The yield was monitored by recording the number of clusters and their total weight from 10 plants per elemental plot (120 per soil treatment and 40 per irrigation treatment).

2.6. Data analysis

ANOVAS were carried out in accordance with GLM procedures, from the $S A S^{\circledR}$ program package (SAS Institute, Cary, NC, USA) and statistical differences between means were assessed by LSD test $(P<0.05)$. The percentage values of plant relative biomass and PPFD were subjected to square root transformation prior to analysis (Gomez and Gomez, 1984). All ANOVAS were done separately per season. 


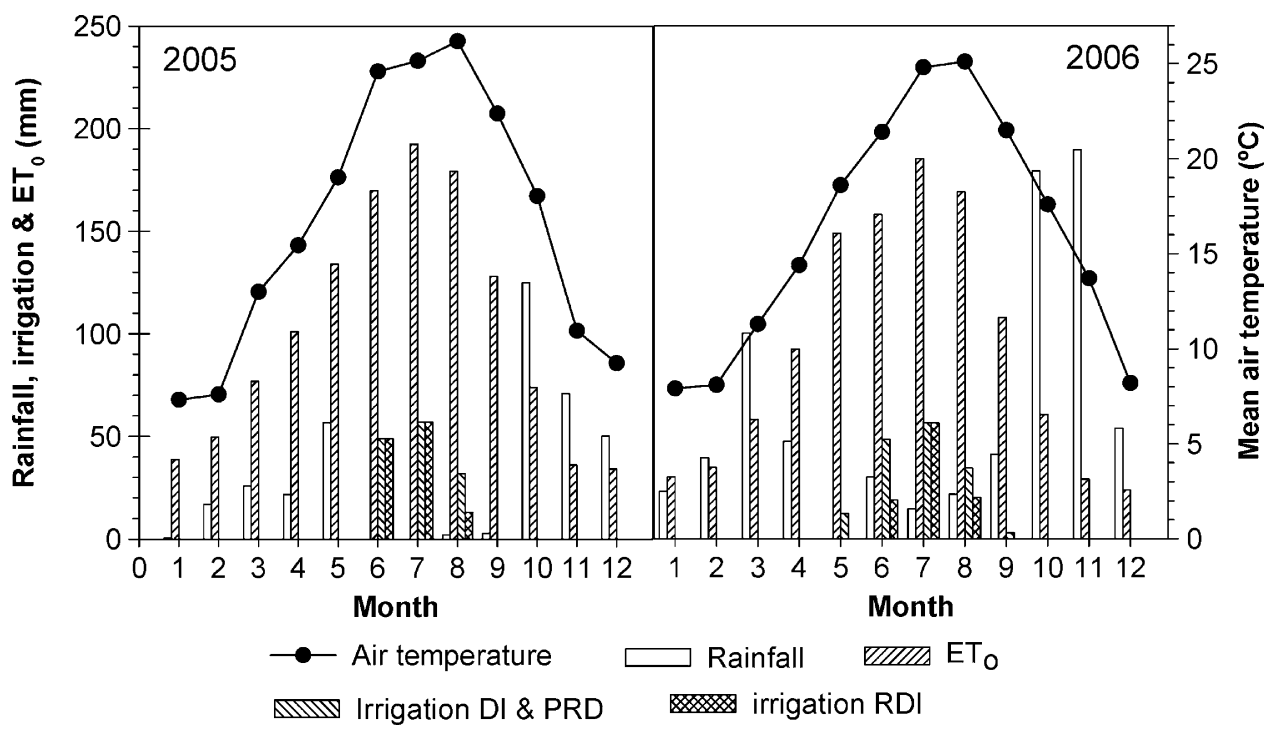

Fig. 1. Mean daily temperature and total monthly rainfall, irrigation and reference evapotranspiration on 2005 and 2006 seasons, at Estremoz, Portugal.

\section{Results}

\subsection{Vegetation dynamics and composition}

During the experimental period the mean air temperature ranged between $7.3{ }^{\circ} \mathrm{C}$ (January 2005) and $26.2^{\circ} \mathrm{C}$ (August 2005). The total amount and distribution of rainfall was very different on the two growing seasons 2005 being a dry year $(372.7 \mathrm{~mm} ; 67 \%$ after harvest) as compared to 2006 ( $740 \mathrm{~mm}$; 63\% after harvest) (Fig. 1).

During the two-year study, at the end of April, plant groups were dominated by annual species on both soil management treatments. The annual broad-leaved species comprised the majority of the species surveyed in both ST and RV treatments. Other plant groups scarcely appeared. In general, no significant differences were detected on the relative biomass of the two soil management treatments except during 2006 where the annual broad-leaved species were significantly higher and the annual grass species lower under the ST treatment as compared to RV (Table 1).

The number of taxa surveyed in April on both years ranged from 29 to 34 but no significant differences were observed between the two soil management treatments. The dominant plant species were the Asteraceae Chamaemelum fuscatum (Brot.) Vasc., Coleostephus myconis L. and Hedypnois cretica (L.) Dumont-Courset, the Brassicaceae Raphanus raphanistrum L., the Fabaceae Medicago polymorpha L., Trifolium glomeratum L. and Trifolium subterraneum L. and the Poaceae Lolium rigidum Gaudin and Vulpia geniculata (L.) Link.

Table 1

Effect of soil management practices on spring (end of April) plant relative biomass (\%) two (2005) and three years (2006) after the experiment set-up. ST - soil tillage; $\mathrm{RV}$ - permanent resident vegetation.

\begin{tabular}{|c|c|c|c|c|}
\hline \multirow[t]{3}{*}{ Plant groups } & \multicolumn{4}{|c|}{ Relative biomass (0-100) } \\
\hline & \multicolumn{2}{|l|}{2005} & \multicolumn{2}{|l|}{2006} \\
\hline & ST & RV & ST & $\mathrm{RV}$ \\
\hline Annual broad-leaved species & $51.8 \mathrm{a}$ & $65.5 a$ & $82.1 \mathrm{a}$ & $71.3 \mathrm{~b}$ \\
\hline Annual grass species & 44.3a & $30.1 \mathrm{a}$ & $17.8 \mathrm{~b}$ & $28.1 \mathrm{a}$ \\
\hline Perennial broad-leaved species & $3.8 \mathrm{a}$ & $4.0 \mathrm{a}$ & $0.1 \mathrm{a}$ & $0.2 \mathrm{a}$ \\
\hline Perennial grass species & $0.0 \mathrm{a}$ & $0.4 \mathrm{a}$ & $0.0 \mathrm{a}$ & $0.4 \mathrm{a}$ \\
\hline Other monocotyledones & $0.0 \mathrm{a}$ & $0.0 \mathrm{a}$ & $0.0 \mathrm{a}$ & $0.0 \mathrm{a}$ \\
\hline
\end{tabular}

For each year, in each row different letter suffixes indicate statistically significant differences at $P<0.05$.
In 2005 the dominant family was the Poaceae followed by Asteraceae and Fabaceae. In 2006 the dominant families were the Fabaceae and Poaceae, being the dominant plant species M. polymorpha (110.8 and $134.4 \mathrm{~g} \mathrm{~m}^{-2}$ above-ground dry matter in ST and $\mathrm{RV}$, respectively) and L. rigidum (68.4 and $104.6 \mathrm{~g} \mathrm{~m}^{-2}$ above-ground dry matter in ST and RV, respectively).

The annual pattern of total vegetation biomass evolution was similar for the two seasons but total vegetation biomass recorded in spring was much higher in 2006 (ca 300\%) than in 2005. In 2006 the above-ground biomass increased gradually from January until the end of April (Fig. 2). In 31 January (DOY 31) and 7 March (DOY 66) the RV treatment presented a significantly higher above-ground dry biomass than ST, but thereafter at the end of April no significant differences were detected. While in RV treatment vegetation soil coverage was always $100 \%$, in the ST treatment soil coverage was $72 \%$ and $81 \%$ at the January and March surveys, respectively. In ST treatment, after the cultivation that was carried out at the end of April, the vegetation was destroyed and the soil stayed bare since then until the autumn. In RV, after the mowing done at the same date as the tillage, the vegetation biomass recovered during May but then dried out during the summer, creating dead mulch (Fig. 2).

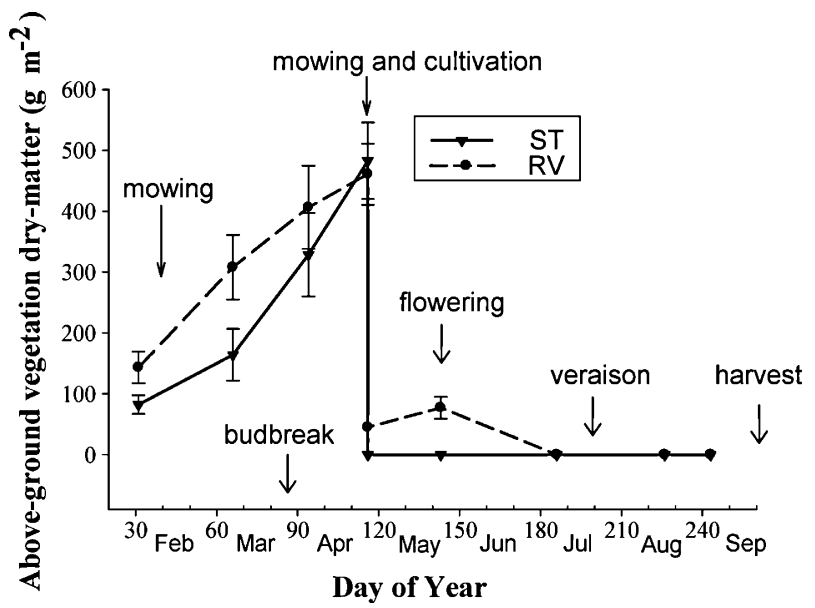

Fig. 2. Effect of soil management practices on the evolution of above-ground vegetation dry matter during 2006. ST - soil tillage; RV - resident vegetation. Mean and standard errors of 24 randomized areas of $0.5 \mathrm{~m}^{2}$ per soil management treatment. 


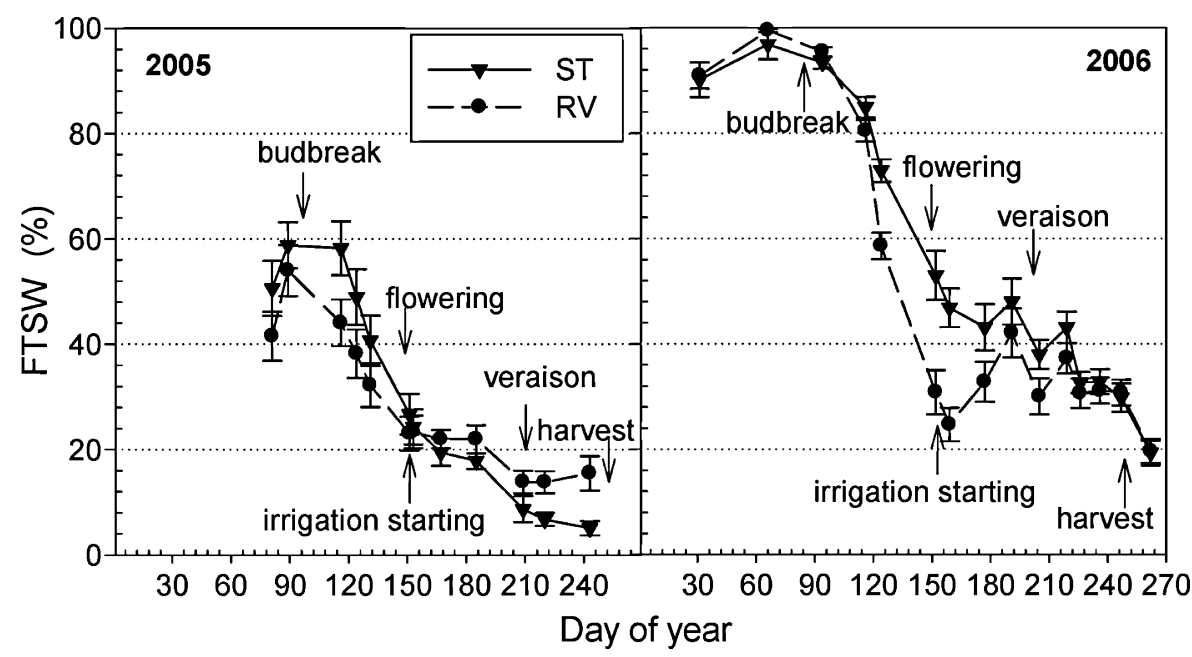

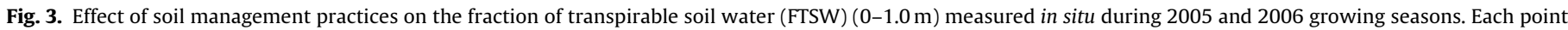
represents the mean and standard error of the measurements made on 16 access tubes.

\subsection{Soil and vine water status}

FTSW in the $0-1.0 \mathrm{~m}$ soil profile measured in situ in 2005 and 2006 showed a decreasing pattern from vine budburst to flowering, when irrigation started (Fig. 3). While in 2006 the soil has attained the field capacity at the beginning of the growing period, in 2005, due to the dryness of the previous winter, the soil water profile was not fully refilled. FTSW values measured at end of each irrigation cycle were always lower than 53\%, 2005 values being much lower than those of the 2006 (Fig. 3). In 2005, from the end of March (budburst, DOY 85) to the end of May (DOY 150) a lower FTSW was observed in RV treatment as compared to ST, although the differences were not always statistically significant. In 2005, from irrigation starting (8th June) until veraison both soil management treatments showed similar FTSW, however, during the ripening period, RV showed a significantly higher FTSW than ST (Fig. 3). During all May 2006 RV showed significantly lower FTSW values than ST. Those differences were maintained during the first two weeks of June (irrigation started at 29th May), but then decreased until veraison after which both soil management treatments presented similar FTSW values until harvest (Fig. 3).

To estimate the water used during the period of more intense plant water competition the amount of water depletion in the first $1.0 \mathrm{~m}$ of soil was calculated separately for three soil layers from 26 April (date of soil cultivation) to the end of May (onset of irrigation) of 2006 (Table 2). In this period, the RV treatment showed a significantly higher total water use as compared to ST (+39\%). Soil water depletion was also significantly higher in each of the three assessed soil layers of RV. While in the RV treatment the extraction was almost uniform from the entire $1.0 \mathrm{~m}$ profile, the ST presented higher extraction from the two upper layers $(0-0.3$; $0.3-0.6 \mathrm{~m})$ than from the deeper one $(0.6-1.0 \mathrm{~m})$. Concerning the relative contribution of each layer during the same period, the sur- face layer $(0-0.3 \mathrm{~m})$ contributed with a higher percentage of water in ST (38\%) than in RV (31\%) while the opposite was observed at the deepest layer (25 vs 34\% for ST and RV respectively).

In 2005, at the start of irrigation vine predawn leaf water potential $\left(\psi_{\text {pd }}\right)$ values were around -0.55 MPa in the two soil management treatments. In $2006 \mathrm{RV}$ presented a significantly lower $\psi_{\text {pd }}(-0.52 \mathrm{MPa})$ than ST $(-0.42 \mathrm{MPa})$ at the start of irrigation (Fig. 4). During the first weeks after watering a slight increase was observed in the $\psi_{\text {pd }}$ (measured at the end of the drying cycle following irrigation), in both soil management treatments and in both years, followed by a gradual decline from the end of June onwards. In 2005, ST vines achieved veraison with a significantly higher $\psi_{\mathrm{pd}}$ than RV, but at harvest an opposite situation was observed (Fig. 4a). In 2006 significantly higher $\psi_{\text {pd }}$ values were observed in ST vines as compared to RV ones throughout the entire season (Fig. 4c). The effects of irrigation treatments on vine $\psi_{\text {pd }}$ were similar in both seasons with the main significant differences observed at the end of the ripening period where RDI showed lower values than PRD (in 2005) or than PRD and DI (in 2006) (Fig. 4b and d).

\subsection{Vine vegetative growth, canopy density and cluster microclimate}

In both seasons the RV treatment significantly reduced shoot length (measured at berry set), leaf area (mainly lateral leaf area), shoot and winter pruning weight as compared to ST (Table 3 ). The effects of irrigation treatments on vine vegetative growth were only statistically significant in 2006, with RDI showing a reduction in winter pruning weight, as compared to PRD, and a lower fraction of lateral leaf area and lower shoot weight than PRD and DI vines (Table 3).

In both seasons ST presented a slightly higher leaf layer number than RV but the differences were never statistically significant. In

Table 2

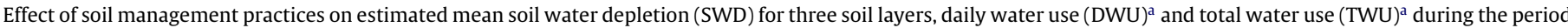
from soil tillage/vegetation mowing (26th April) to onset of irrigation (29th May) of 2006 season. ST - soil tillage; RV - permanent resident vegetation.

\begin{tabular}{|c|c|c|c|c|c|}
\hline \multirow[t]{2}{*}{ Soil management } & \multicolumn{3}{|c|}{$\mathrm{SWD}(\mathrm{mm})$} & \multirow{2}{*}{$\begin{array}{l}\mathrm{DWU}(\mathrm{mm} / \mathrm{day}) \\
0-1.0 \mathrm{~m}\end{array}$} & \multirow[t]{2}{*}{ TWU $(\mathrm{mm}$} \\
\hline & $0-0.3 \mathrm{~m}$ & $0.3-0.6 \mathrm{~m}$ & $0.6-1.0 \mathrm{~m}$ & & \\
\hline ST & $19.8 b$ & $19.9 b$ & $12.9 \mathrm{~b}$ & $1.9 \mathrm{~b}$ & $64.6 \mathrm{~b}$ \\
\hline RV & $23.8 \mathrm{a}$ & $27.8 \mathrm{a}$ & $26.4 a$ & $2.7 a$ & $90.0 \mathrm{a}$ \\
\hline
\end{tabular}

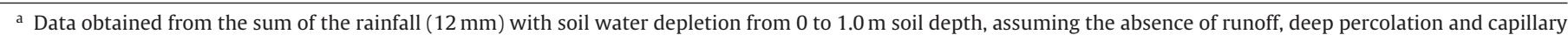
rise of groundwater. In each column different letter suffixes indicate statistically significant differences at $P<0.05$. 


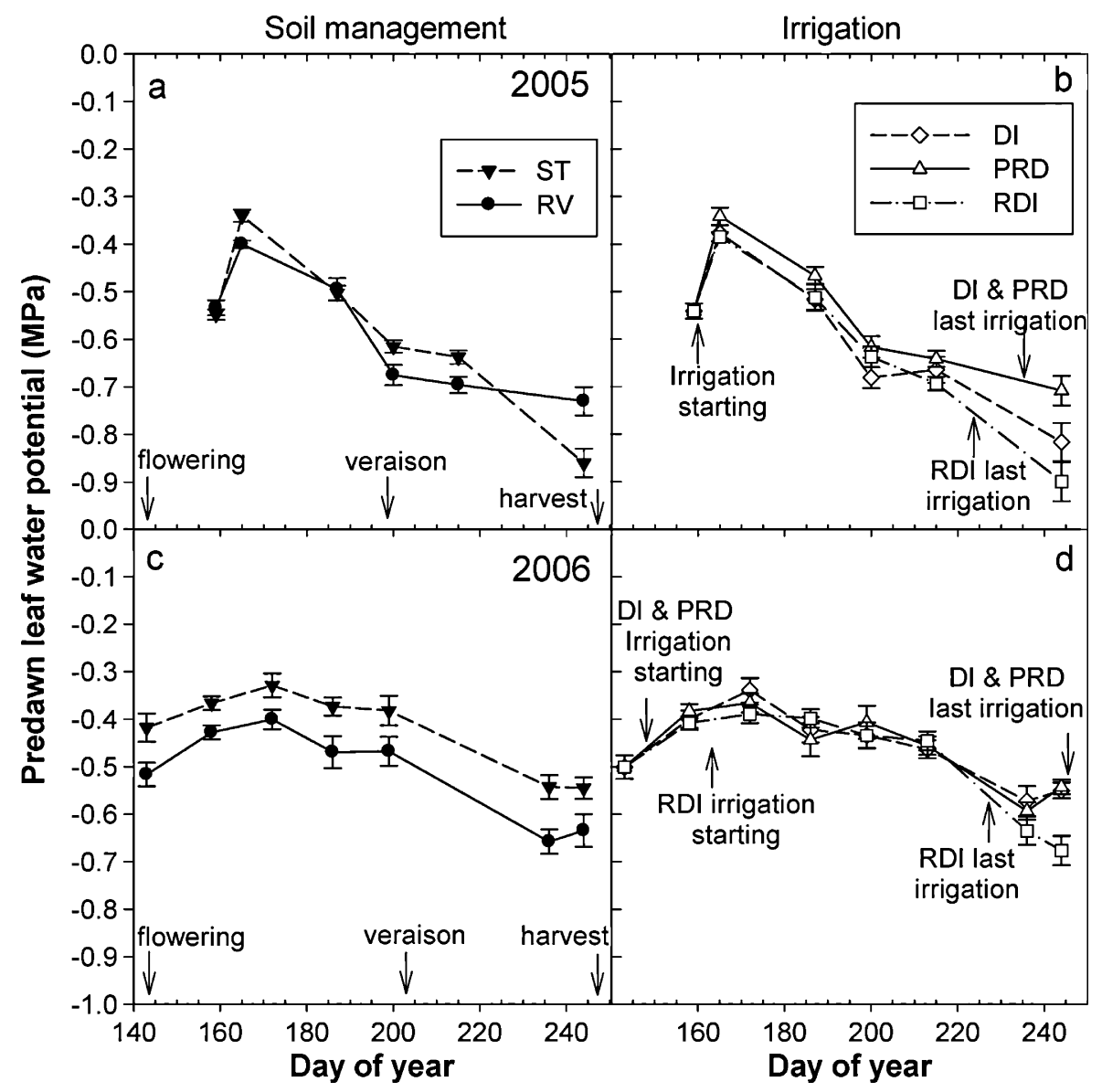

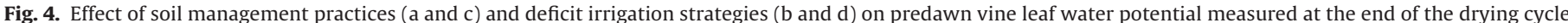

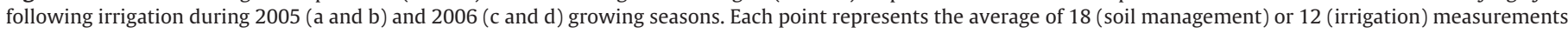
with the standard error.

2006 ST showed a significantly lower fraction of intercepted light at the cluster zone than RV. The irrigation treatments presented no significant differences either in the leaf layer number and light intercepted at the cluster zone (Table 3).
No significant differences in leaf blade nitrogen content were found either between ST and RV (3.02 and 2.92\% respectively) or among irrigation treatments $(2.96,2.97$ and $2.99 \%$ respectively for DI, PRD and RDI).

Table 3

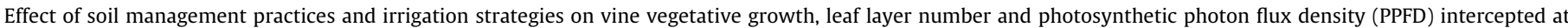

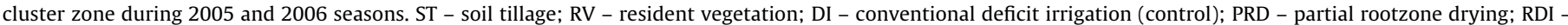
regulated deficit irrigation.

\begin{tabular}{|c|c|c|c|c|c|c|c|c|}
\hline Source of variation & Shoot no/vine & Shoot length $(\mathrm{m})^{\mathrm{a}}$ & Total LA ${ }^{\mathrm{b}}\left(\mathrm{m}^{2} /\right.$ vine $)$ & Lateral LA ${ }^{\mathrm{b}}(\%)$ & Pruning wt (kg/vine) & Shoot wt (g) & $\operatorname{PPFD}(\%)^{\mathrm{c}}$ & Leaf layer no \\
\hline \multicolumn{9}{|l|}{2005} \\
\hline Soil Manag. & ns & $*$ & $*$ & * & * & * & & ns \\
\hline ST & 14.9 & $1.38 \mathrm{a}$ & $5.0 \mathrm{a}$ & $21.9 \mathrm{a}$ & $0.46 \mathrm{a}$ & $30.9 \mathrm{a}$ & & 2.8 \\
\hline RV & 13.7 & $1.13 \mathrm{~b}$ & $3.7 \mathrm{~b}$ & $8.7 \mathrm{~b}$ & $0.32 \mathrm{~b}$ & $23.4 \mathrm{~b}$ & & 2.4 \\
\hline Irrigation & ns & ns & ns & ns & ns & ns & nc & ns \\
\hline DI & 14.3 & 1.26 & 4.7 & 14.7 & 0.40 & 28.0 & & 2.6 \\
\hline PRD & 14.1 & 1.26 & 4.3 & 16.5 & 0.39 & 27.7 & & 2.6 \\
\hline RDI & 14.4 & 1.23 & 4.1 & 14.8 & 0.38 & 26.4 & & 2.5 \\
\hline Interaction & ns & ns & ns & ns & ns & ns & & ns \\
\hline \multicolumn{9}{|l|}{2006} \\
\hline Soil Manag. & ns & $*$ & $*$ & $*$ & * & * & $*$ & ns \\
\hline ST & 18.1 & $1.39 a$ & $5.9 \mathrm{a}$ & $22.2 \mathrm{a}$ & $0.62 a$ & $34.3 \mathrm{a}$ & $18.7 \mathrm{a}$ & 3.5 \\
\hline RV & 17.2 & $1.07 \mathrm{~b}$ & $4.5 \mathrm{~b}$ & $12.8 \mathrm{~b}$ & $0.40 \mathrm{~b}$ & $23.3 \mathrm{~b}$ & $29.2 \mathrm{~b}$ & 3.3 \\
\hline Irrigation & ns & $*$ & ns & $*$ & $*$ & $*$ & ns & ns \\
\hline DI & 17.0 & $1.29 \mathrm{a}$ & 5.3 & $19.1 \mathrm{a}$ & $0.52 \mathrm{ab}$ & $30.6 \mathrm{a}$ & 25.4 & 3.5 \\
\hline PRD & 18.0 & $1.27 \mathrm{a}$ & 5.4 & $20.1 \mathrm{a}$ & $0.57 \mathrm{a}$ & $31.7 \mathrm{a}$ & 22.0 & 3.2 \\
\hline RDI & 17.9 & $1.13 \mathrm{~b}$ & 4.9 & $13.3 \mathrm{~b}$ & $0.45 \mathrm{~b}$ & $25.1 \mathrm{~b}$ & 24.6 & 3.5 \\
\hline Interaction & ns & ns & ns & ns & ns & ns & ns & ns \\
\hline
\end{tabular}

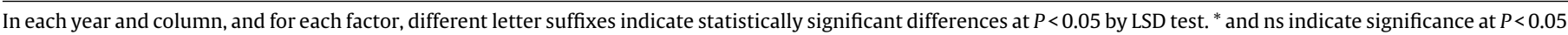
and not significant, respectively. LA - leaf area; nc - data not collected.

a Measured at fruitset.

b Measured at mid-ripening.

c Measured at mid-ripening at cluster zone. 
Table 4

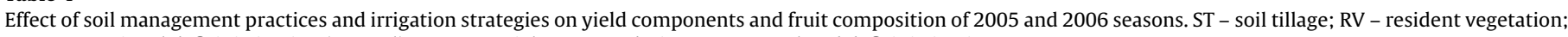
DI - conventional deficit irrigation (control); PRD - partial rootzone drying; RDI - regulated deficit irrigation.

\begin{tabular}{|c|c|c|c|c|c|c|c|c|c|}
\hline Source of variation & Cluster no/vine & Berry wt (g) & Cluster wt (g) & Yield (kg/vine) & TSS ( ${ }^{\circ}$ Brix $)$ & $\mathrm{TA}(\mathrm{g} / \mathrm{L})$ & $\mathrm{pH}$ & Total phenols (TPI) & Antocyanins (mg/g) \\
\hline \multicolumn{10}{|l|}{2005} \\
\hline Soil Manag. & ns & * & * & * & $*$ & * & ns & ns & ns \\
\hline ST & 15.3 & $1.54 \mathrm{a}$ & $241.8 \mathrm{a}$ & $3.70 \mathrm{a}$ & $20.5 b$ & $4.86 \mathrm{a}$ & 3.46 & 58.9 & 0.43 \\
\hline RV & 14.9 & $1.45 \mathrm{~b}$ & 194.6 b & $2.90 \mathrm{~b}$ & $21.1 \mathrm{a}$ & $4.50 \mathrm{~b}$ & 3.52 & 54.8 & 0.46 \\
\hline Irrigation & ns & ns & ns & ns & ns & ns & ns & ns & ns \\
\hline $\mathrm{DI}$ & 15.7 & 1.48 & 212.7 & 3.34 & 21.0 & 4.68 & 3.50 & 55.1 & 0.42 \\
\hline PRD & 14.3 & 1.51 & 232.2 & 3.32 & 20.7 & 4.80 & 3.48 & 57.8 & 0.46 \\
\hline RDI & 15.5 & 1.50 & 209.0 & 3.24 & 20.6 & 4.56 & 3.50 & 57.6 & 0.45 \\
\hline Interaction & ns & ns & ns & ns & ns & ns & ns & ns & ns \\
\hline \multicolumn{10}{|l|}{2006} \\
\hline Soil Manag. & ns & * & * & * & ns & $*$ & ns & ns & ns \\
\hline ST & 19.9 & $1.59 \mathrm{a}$ & $182.4 \mathrm{a}$ & $3.65 \mathrm{a}$ & 22.8 & $3.98 \mathrm{a}$ & 3.27 & 30.0 & 0.32 \\
\hline RV & 19.8 & $1.49 \mathrm{~b}$ & $150.0 \mathrm{~b}$ & $3.00 \mathrm{~b}$ & 22.8 & $3.37 \mathrm{~b}$ & 3.36 & 28.0 & 0.34 \\
\hline Irrigation & ns & $*$ & $* *$ & $* *$ & ns & $*$ & ns & ns & ns \\
\hline DI & 19.3 & $1.59 \mathrm{a}$ & $177.4 \mathrm{a}$ & $3.42 \mathrm{a}$ & 22.5 & $3.79 \mathrm{a}$ & 3.29 & 26.2 & 0.32 \\
\hline PRD & 20.3 & $1.56 \mathrm{ab}$ & $177.7 \mathrm{a}$ & $3.61 \mathrm{a}$ & 22.4 & $3.75 \mathrm{a}$ & 3.29 & 29.5 & 0.34 \\
\hline RDI & 20.0 & $1.47 \mathrm{~b}$ & $143.7 \mathrm{~b}$ & $2.88 \mathrm{~b}$ & 23.5 & $3.49 \mathrm{~b}$ & 3.37 & 30.8 & 0.34 \\
\hline Interaction & ns & ns & ns & ns & ns & ns & ns & ns & ns \\
\hline
\end{tabular}

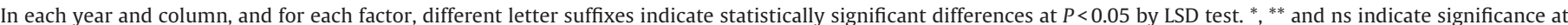
$P<0.05,0.01$ and not significant, respectively. TSS - total soluble solids; TA - titratable acidity; TPI - total phenols index.

No significant interactions were detected between soil management and irrigation treatments with regard to vine vegetative growth and canopy density attributes.

\subsection{Yield and berry composition}

RV treatment significantly reduced berry size, cluster weight and yield when compared to ST. Concerning the effects produced by irrigation on yield and its components, no significant differences were observed among treatments in 2005, whereas in 2006 RDI showed a significant reduction in berry size, cluster weight and yield when compared to PRD (except for berry size) and DI, the values for which were similar to one another (Table 4).

The effects of soil management treatments on fruit composition were statistically significant for juice soluble solids in 2005 (slightly higher in RV than in ST) and for titratable acidity in both seasons, RV showing lower acidity than ST. In both seasons the three irrigation treatments presented similar fruit composition except for the titratable acidity in 2006, which was significantly lower in RDI as compared to DI and PRD (Table 4).

No significant interactions were detected between soil management and irrigation treatments with regard to yield and berry composition attributes.

\section{Discussion}

\subsection{Soil management}

The different weather patterns in the two years of the study probably influenced vegetation growth during spring. The amount and distribution of rainfall until the end of April seems to be the most important variable to explain the differences in the total amount of cover crop above-ground vegetation biomass registered in each year. The higher biomass values recorded in RV treatment during the winter of 2006 may be explained by the reduction of soil compaction and the improvement of soil structure in the soil top layers (not measured) by the cover crops as suggested by Folorunso et al. (1992) and Geoffrion (2000). On the other hand, the absence of significant differences between the two soil management treatments in the biomass surveyed at the end of April 2006 may be justified by a higher growth rate of ST vegetation caused by the lower interspecies competition mainly for light due to the lower soil coverage (Liu et al., 2009).
The higher soil water depletion presented by the RV treatment during spring as compared to ST can be attributed to the higher water use caused by the higher amount and different composition of the vegetation biomass. For example, in $2006 \mathrm{RV}$ presented $0.8 \mathrm{~mm} /$ day of additional mean water use during all May (Table 2). These values of additional water use are within the range of those reported in the literature (e.g. Böll, 1967; Griebel, 1996; Monteiro and Lopes, 2007). Besides the differences in total water use during spring, the two soil management treatments presented different patterns of water extraction through the profile, as also reported in other studies (e.g. Morlat and Jacquet, 2003; Monteiro and Lopes, 2007; Celette et al., 2008). As stated by Morlat and Jacquet (2003), the competition between the resident vegetation and the vine reduces the number of vine roots in the inter-row but induces the development of a deeper root system in the vine row in order to explore the more wetted layers. A similar behavior could be suggested as an explanation for the higher water depletion observed in the $60-100 \mathrm{~cm}$ layers on the RV as compared to ST (vide Table 2) during may.

The differences between the two soil management treatments observed in the FTSW during spring disappeared (2006) or were reversed (2005) during the ripening period (Fig. 3). This behavior is similar to that observed in a non-irrigated Cabernet Sauvignon vineyard by Monteiro and Lopes (2007) and can be explained by a larger evapotranspiration in ST caused by the combination of higher vine leaf area and the likely higher soil evaporation that is to be expected from bare soil. The likely lower soil evaporation caused by the mulching effect of cover cropping residues (Skrotch and Shribbs, 1986; Prichard, 1998) in RV can also contribute to attenuate the differences in FTSW between the two soil management treatments during the ripening period.

Irrigation started with $\psi_{\text {pd }}$ values that indicate a moderate to weak water deficit in grapevines (Ojeda et al., 2002; Van Leewen et al., 2009), suggesting that irrigation might have been initiated late. However, in this wine region, for premium red wines and when the canopy has already attained the required development at bloom, it is common to start irrigation only when expanding leaves begin to grow beyond the shoot tip, indicating that shoot growth is beginning to slow down or even stop. With this practice the growers avoid promoting an excessive vegetative growth after the first irrigation in order to reduce summer pruning, save water and maintain the vines with low vigor. Indeed, in ST, the beginning of irrigation fitted with that strategy as when irrigation started ( $\sim$ fruit set) the 
canopy had already achieved the desired development with a good replenishment of all the trellis system ( $1.2 \mathrm{~m}$ canopy height). By contrast, in RV, we observed an incomplete trellis replenishment caused by a lower shoot development, indicating that, as compared to ST, the higher water use by the cover crops in spring induced an earlier stop in shoot growth.

A direct consequence of the reduced shoot length in RV, as compared to ST, was a reduction in the vine leaf area, the effects being more pronounced on the lateral than on the main leaf area as was also observed by Lopes et al. (2008). The reduction of vine vegetative growth in RV as compared to ST has been mainly attributed to the competition for water (Morlat, 1987; Celette et al., 2005; Monteiro and Lopes, 2007; Sanguankeo et al., 2009). Nevertheless, other studies using cover crops showed that the reduction in nitrogen uptake and storage in aerial parts can also contribute for reduced vine shoot growth (Maigre and Aerny, 2001; Wade et al., 2004; Tesic et al., 2007; Celette et al., 2009). In the current experiment, however, we found no significant differences in leaf nitrogen content, which suggests that water competition was the main factor contributing to the observed differences in vegetative growth between the two soil management treatments.

It has been shown that water deficits affect fruit growth less than vegetative growth (Matthews et al., 1987; McCarthy, 1997; McCarthy, 1999); however, in our study the competition for water by the cover crop induced also a significant reduction in yield, results that agree with most of the reported studies (Geoffrion, 2000; Maigre and Aerny, 2001; Tesic et al., 2007). Despite the differences in yield, the major and consistent effect of the soil management treatments on berry composition was the reduction of must titratable acidity induced by RV as compared to ST.

The lower plant water status combined with higher light penetration at the cluster zone in the RV treatment relative to ST, could explain the lower must titratable acidity of RV treatment. In fact, must acidity was shown to decline with water and heat stress due to an accelerated decrease in malic acid (Esteban et al., 1999; Williams and Matthews, 1990).

\subsection{Irrigation}

The effects of irrigation treatments were not much pronounced; with significant differences among irrigation treatments only observed in 2006. While DI and PRD presented similar results, RDI reduced vine vegetative growth, berry weight and yield as compared to DI and PRD. The reduction in vine vegetative growth is in accordance with other RDI experiments in which water deficit has been imposed at berry set (McCarthy et al., 2002; Wample and Smithyman, 2002), thus underlining the importance of early water deficits to control vine vegetative growth. Imposing a water stress period after veraison is an irrigation strategy used to enhance anthocyanin accumulation (Dry et al., 2001) by an indirect effect via the improvement of cluster zone microclimate led by the reduction of vine vegetative growth (Bergqvist et al., 2001; Spayd et al., 2002). However, in the current experiment this effect was not evident. Despite the low vigor observed in RDI in 2006, as compared to the other irrigation treatments, we have not observed any significant differences on leaf layer number nor on the light microclimate at cluster zone. This suggests that, in this low vigor vineyard, the reduction in vegetative growth observed in RDI has not been strong enough to change cluster microclimate.

A significant reduction of berry weight by RDI only occurred in 2006, when water deficits were imposed at berry set and preharvest, showing that berry size is more sensitive to water deficit before veraison than afterwards. This was also described for other grapevine varieties (e.g. Matthews and Anderson, 1988 with Cabernet Franc, McCarthy, 1997 with Syrah and Salón et al., 2005 with Bobal). The reduction of berry weight may improve berry skin anthocyanins via the increase of the skin/pulp ratio (McCarthy et al., 2002) however in the current study no significant differences were observed.

The absence of significant differences between PRD and DI treatments in vegetative growth, yield and yield components is consistent with previous field studies (Bravdo et al., 2004; Dry et al., 2001; Gu et al., 2004; Pudney and McCarthy, 2004; Baeza and Lissarrague, 2005). However, other PRD grapevine studies showed that PRD exerted a better control of vegetative growth and produced a better grape quality than the conventional deficit irrigation, receiving the same amount of water (e.g., Santos et al., 2005; Antolin et al., 2006). Those contrasting results in different PRD experiments may be caused by differences in the susceptibility of the variety to water stress (Chaves et al., 2010; Flexas et al. 2010) but other factors are also likely to intervene (Dodd, 2009). The prevalent rainfall, temperature and evaporative demand in the region, the type of soil and the frequency of switching irrigation in PRD may dictate the intensity of the chemical signaling that is proposed to underlie plant responses to this form of irrigation. For example, the type of soil may have an impact on the extent of soil water redistribution that in turn will buffer dehydration in the dry rootzone. In fact, Bravdo (2005) suggests that hydraulic redistribution from deeper to shallower roots may prevent that the clear results obtained in potted plants subjected to PRD irrigation, are achieved under field conditions. Dry (2005) also stated that PRD might not be successful in conditions where soil porosity favours lateral spread of irrigation water. As in the current experiment the soil has a silty clay loam texture it is likely that separation of the wet and drying rootzones, and therefore the onset of chemical signaling, could have not been so clear as in the vines growing in sandy soils (e.g. Santos et al., 2003).

The absence of differences on vine vegetative growth, canopy density and cluster light microclimate might explain why no apparent differences were observed in fruit composition between PRD and DI at the current experiment.

As no soil management-by-irrigation interactions were detected it can be inferred that the soil management did not influence the vines' response to deficit irrigation strategies.

\section{Conclusions}

Compared to soil tillage the resident vegetation was effective in reducing soil water content during spring, thus inducing a significant decrease in vine vegetative growth, berry weight, yield and must titratable acidity. The effects of the irrigation strategy were observed only in the second season, when RDI induced a significant reduction on vine vegetative growth, berry weight, yield and titratable acidity as compared to PRD and DI.

Our work shows evidence that, in low vigor vineyards and with low irrigation amounts, PRD was unable to induce better agronomical results than the conventional deficit irrigation strategy. Due to the lack of improvement on berry composition there is no incentive for growers to use PRD instead of DI under such conditions, as PRD has higher installation costs and is an irrigation technique more difficult to implement.

The current study also demonstrates that RDI is an efficient irrigation strategy to control shoot growth and reduce berry size mainly when water deficit is applied at berry set. However, in low vigor vineyards such as ours, RDI is not an alternative to the conventional deficit irrigation as it has induced a loss in yield without any improvement on berry composition and, ultimately, with no financial reward for the growers. For the ecological and viticultural conditions of our experiment, it can be concluded that the amount of irrigation water applied, rather than the method of irrigation, had a more significant effect on vegetative growth and yield. In 
this situation the conventional sustained deficit irrigation should be preferred to RDI and PRD as it is the simplest deficit irrigation strategy and has enabled an efficient control of vegetative growth without any negative impact on yield and berry composition as compared to the other irrigation treatments.

The combination of cover cropping and deficit irrigation can be a valuable tool in Mediterranean irrigated vineyards to control high spring vegetative growth. However, the degree of water competition between cover crops and vine must be carefully monitored and managed (e.g. by increasing mowing frequency) and adjustments in conventional irrigation management are necessary.

\section{Acknowledgements}

We thank to the estate "Monte Seis Reis" for the experimental vineyard facilities. J.M. Costa and T. Santos are supported by fellowships granted by Fundação para a Ciência e Tecnologia (FCT). WATERWEB, POCI/AGR/59079/2004 and PPCDT/AGR/61980/2004 projects provided funds to support part of the research presented.

\section{References}

Afonso, J.M., Monteiro, A., Lopes, C.M., Lourenço, J., 2003. Enrelvamento do solo em vinha na região dos Vinhos Verdes. Três anos de estudo na casta 'Alvarinho'. Ciênc. Téc. Vitiv. 18, 47-63.

Allen, R.G., Pereira, L.S., Raes, D., Smith, M., 1998. Crop evapotranspiration. Guidelines for computing Crop Water Requirements. FAO irrigation and drainage paper no. 56, Rome.

Antolin, M.C., Ayari, M., Sanchez-Dias, M., 2006. Effects of partial rootzone drying on yield, ripening and berry ABA in potted Tempranillo grapevines with split roots. Aust. J. Grape Wine Res. 12, 13-20.

Battilani, A., 2000. Application of the regulated deficit irrigation to grapevines Vitis vinifera in a sub-humid area. Acta Hort. 537, 887-893.

Bergqvist, J., Dokoozlian, N., Ebisuda, N., 2001. Sunlight exposure and temperature effects on berry growth and composition of Cabernet Sauvignon and Grenache in the Central San Joaquin Valley of California. Am. J. Enol. Vitic. 52, 1-7.

Böll, K.P., 1967. Versuche zur Gründüngung im Weinbau. Vitis 6, 151-176.

Baeza, P., Lissarrague, J.R., 2005. Agronomic and ecophysiological responses of fieldgrown Cabernet Sauvignon grapevines to three irrigation treatments. Acta Hort 689, 373-379.

Bravdo, B., 2005. Physiological mechanisms involved in the production of nonhydraulic root signals by partial rootzone drying - a review. Acta Hort. 689, 267-275.

Bravdo, B., Naor, A., Zahavi, T., Gal, Y., 2004. The effects of water stress applied alternatively to part of the wetting zone along the season PRD-partial rootzone drying on wine quality, yield, and water relations of red wine grapes. Acta Hort. 664, 101-109.

Caspari, H.W., Neal, S., Naylor, A., 1997. Cover crop management in vineyards to enhance deficit irrigation in a humid climate. Acta Hort. 449, 313-320.

Celette, F., Wery, J., Chantelot, E., Cellete, J., Gary, C., 2005. Belowground interactions in a vine Vitisvinifera L.-tall fescue Festuca arundinacea Shreb. intercropping system: water relations and growth. Plant Soil 276, 205-217.

Celette, F., Gaudin, R., Gary, C., 2008. Spatial and temporal changes to the water regime of a Mediterranean vineyard due to the adoption of cover cropping. Eur. J. Agron. 29, 153-162.

Celette, F., Findeling, A., Gary, C., 2009. Competition for nitrogen in an unfertilized intercropping system: the case of an association of grapevine and grass cover in a Mediterranean climate. Eur. J. Agron. 30, 41-51.

Chaves, M.M., Zarrouk, O., Francisco, R., Costa, J.M., Santos, T., Regalado, A.P., Rodrigues, M.L., Lopes, C.M., 2010. Grapevine under deficit irrigation - hints from physiological and molecular data. Ann. Bot. 105, 661-676.

Derksen, D.A., Lafond, G.P., Thomas, A.G., Loeppky, H.A., Swanton, C.J., 1993. Impact of agronomic practices on weed communities: tillage systems. Weed Sci. 41, 409-417.

Dodd, I.C., Stikic, R., Davies, W.J., 1996. Chemical regulation of gas exchange and growth of plants in drying soil in the field. J. Exp. Bot. 47, 1475-1490.

Dodd, I.C., 2009. Rhizosphere manipulations to maximize 'crop per drop' during deficit irrigation. J. Exp. Bot. 60, 2454-2459.

Dokoozlian, N.K., Kliewer, W.M., 1996. Influence of light on grape berry growth and composition varies during fruit development. J. Am. Soc. Hort. Sci. 121, 869-874.

Dry, P.R., 2005. Use of irrigation strategies for maximization of water use efficiency and wine quality in Australia. In: Proceedings of the International Symposium on Irrigation Management in Wine and Table Grape Vineyards, INIA, Santiago, Chile, pp. 15-22.

Dry, P., Loveys, B.R., 1998. Factors influencing grapevine vigour and the potential for control with partial rootzone drying. Aust. J. Grape Wine Res. 4, 140-148.

Dry, P.R., Loveys, B.R., Botting, D., During, H., 1996. Effects of partial root-zone drying on grapevine vigor, yield, composition of fruit and use of water. In: Proceedings of the 9th Australian Wine Industry Technical Conference Viticultural Publishing , Adelaide, pp. 126-131.

Dry, P.R., Loveys, B.R., McCarthy, M.G., Stoll, M., 2001. Strategic irrigation management in Australian vineyards. J. Int. Sci. Vigne Vin. 35, 129-139.

English, J., Bledsoe, A., Marois, J., Kliewer, W., 1990. Influence of grapevine canopy management on evaporative potential in the fruit zone. Am. J. Enol. Vitic. 41, 137-141.

Esteban, M.A., Villanueva, M.J., Lissarrague, J.R., 1999. Effect of irrigation on changes in berry composition of Tempranillo during maturation. Sugars, organique acids and mineral elements. Am. J. Enol. Vitic. 50, 418-433.

Flexas, J., Galmés, J., Gallé, A., Gulias, J., Pou, A., Ribas-Carbo, A., Tomás, A., Medrano, H., 2010. Improving water use efficiency in grapevines: potential physiological targets for biotechnological improvement. Aust. J. Grape Wine Res. 16, 106-121.

Folorunso, O.A., Rolston, D.E., Prichard, T., Louie, D.T., 1992. Soil surface strength and infiltration rate as affected by winter cover crops. Soil Technol. 5, 189-197.

Geoffrion, R., 1999. L'enherbement permanent, 40 ans aprés. Phytoma 519, 25-27.

Geoffrion, R., 2000. L'enherbement permanent contrôlé des sols viticoles. Vingt ans de recherches sur le terrain en Anjou. Phytoma 530, 28-31.

Gomez, K.A., Gomez, A.A., 1984. Statistical Procedures for Agricultural Research. John Wiley and Sons, New York.

Goodwin, I., 2002. Water management - a tool for vineyard managers. In: Proceedings Seminar Managing Water, ASVO, Mildura, Adelaide, pp. 19-23.

Griebel, T., 1996. Untersuchungen über die Anteile der Transpiration der Rebe und der Evaporation in begrünten Rebbeständen an der Gesamtverdunstung. Geisenheimer Berichte 28, 183-187.

Gu, S.L., Du, G.Q., Zoldoske, D., Hakim, A., Cochran, R., Fugelsang, K., Jorgensen, G., 2004. Effects of irrigation amount on water relations, vegetative growth, yield and fruit composition of Sauvignon blanc grapevines under partial rootzone drying and conventional irrigation in the San Joaquin Valley of California, USA J. Hort. Sci. Biotechnol. 79, 26-33.

Gulick, S.H., Grimes, D.W., Munk, D.S., Goldhamer, D.A., 1994. Cover-crop-enhanced water infiltration of a slowly permeable fine sandy loam soil. J. Soil Sci. Soc. Am. $58,1539-1546$

Hirschfelt, D.J., 1998. Soil fertility and wine nutrition. In: Ingels, C.A., Bugg, R.L. McGourty, G.T., Christensen, L.P. (Eds.), Cover Cropping in Vineyards. A Grower's Handbook. University of California, Oakland, pp. 61-79.

Horneck, D.A., Miller, R.O., 1998. Determination of total nitrogen in plant tissue. In: Kalra, Y.(Ed.), Handbook of Reference Methods for Plant Analysis. CRC Press LLC, Boca Raton, Florida, pp. 75-83.

Ingels, C.A., Scow, K.M., Whisson, D.A., Drenovsky, R.E., 2005. Effects of cover crops on grapevines, yield, juice composition, soil microbial ecology and gopher activity. Am. J. Enol. Vitic. 56, 19-29.

IPCC, 2007. Climate Change 2007: The Physical Basis Summary for Policy Makers. Cambridge University Press, Cambridge.

Keller, M., Hrazdina, G., 1998. Interaction of nitrogen availability during bloom and light intensity during veraison. II. Effects on anthocyanin and phenolic development during grape ripening. Am. J. Enol. Vitic. 49, 341-349.

Keller, M., Smithyman, R.P., Mills, L.J., 2008. Interactive effects of deficit irrigation and crop load on Cabernet Sauvignon in an arid climate. Am. J. Enol. Vitic. 59 (3), 221-234.

Linares, R., Fuente, M., Junquera, P., Baeza, P., 2007. Response of a Merlot vineyard to several soil management practices in a Mediterranean environment. In: Proceedings XV GESCO International Symposium, Croatia Institute of Agriculture and Tourism, Porec, pp. 371-377.

Liu, J.G., Mahoney, K.J., Sikkem, P.H., Swanton, C.J., 2009. The importance of light quality in crop-weed competition. Weed Res. 49, 217-224.

Lopes, C.M., Monteiro, A., Rückert, F.E., Gruber, B., Steinberg, B., Schultz, H.R., 2004 Transpiration of grapevines and co-habitating cover crop and weed species in a vineyard. A "snapshot" at diurnal trends. Vitis 43, 111-117.

Lopes, C.M., Pinto, P.A., 2005. Easy and accurate estimation of grapevine leaf area with simple mathematical models. Vitis 44, 55-61.

Lopes, C.M., Monteiro, A., Machado, J.P., Fernandes, N., Araújo, A., 2008. Cover cropping in a slopping non-irrigated vineyard: II - effects on vegetative growth, yield, berry and wine quality of 'Cabernet Sauvignon' grapevines. Ciênc. Téc. Vitiv. 23, 37-43.

Loveys, B.R., Dry, P.R., Stoll, M., McCarthy, M.G., 2000. Using plant physiology to improve the water efficiency of horticultural crops. Acta Hort. 537, 187-197.

Loveys, B.R., Stoll, M., Davies, W.J., 2004. Physiological approaches to enhance wate use efficiency in agriculture: exploiting plant signalling in novel irrigation practice. In: Bacon, M.A. (Ed.), Water Use Efficiency in Plant Biology. University of Lancaster, Lancaster, UK, pp. 113-141.

Maigre, D., Aerny, J., 2001. Enherbement permanent et fumure azotée sur cv. 'Gamay' dans le Valais Central. Revue Suisse Vitic. Arbor. Hort. 33, 343-349.

Matthews, M.A., Anderson, M.M., 1988. Fruit ripening in Vitisvinifera L.: responses to seasonal water deficits. Am. J. Enol. Vitic. 39, 313-320.

Matthews, M.A., Anderson, M.M., Schultz, H.R., 1987. Phenologic and growth responses to early and late season water deficits in Cabernet Franc. Vitis 26, 147-160.

McCarthy, M.G., 1997. The effect of transient water deficit on berry development of Shiraz Vitisvinifera L. Aust. J. Grape Wine Res. 3, 102-108.

McCarthy, M.G., 1999. Weight loss from ripening berries of Shiraz grapes Vitisvinifera L. cv. Shiraz. Aust. J. Grape Wine Res. 5, 10-16.

McCarthy, M.G., Loveys, B.R., Dry, P.R., Stoll, M., 2002. Regulated deficit irrigation and partial rootzone drying as irrigation management techniques for grapevines. In: FAO (Eds.), Deficit Irrigation Practices, Rome, pp. 79-88. 
Monteiro, A., Lopes, C.M., 2007. Influence of cover crop on water use and performance of vineyard in Mediterranean Portugal. Agric. Ecosyst. Environ. 121, 336-342.

Morlat, R., 1987. Influence du mode d'entretien du sol surl'alimentation en eau de la vigne en Anjou. Consequences agronomiques. Agronomie 7, 183-191.

Morlat, R., Jacquet, A., 2003. Grapevine root system and soil characteristics in a vineyard maintained long-term with or without interrow sward. Am. J. Enol. Vitic. $54,1-7$.

OIV, 1990. Recueil des méthodes internationales dǐanalyses des vins et des moûts. Office International de la Vigne et du Vin, Paris.

Ojeda, H., Andary, C., Kraeva, E., Carbonneau, A., Deloire, A., 2002. Influence of preand postveraison water deficits on synthesis and concentration of skin phenolic compounds during berry growth of Vitisvinifera cv. Shiraz. Am. J. Enol. Vitic. 53, 261-267.

Pellegrino, A., Lebon, E., Voltz, M., Wery, J., 2004. Relationships between plant and soil water status in vine Vitisvinifera L. Plant Soil 266, 129-142.

Prichard, T.L., 1998. Water use and infiltration. In: Ingels, C.A., Bugg, R.L., McGourty, G.T., Christensen, L.P. (Eds.), Cover Cropping in Vineyards. A Grower's Handbook. University of California, Oakland, pp. 86-90.

Pudney, S., McCarthy, M.G., 2004. Water use efficiency of field grown chardonnay grapevines subjected to partial rootzone drying and deficit irrigation. Acta Hort. $664,567-573$.

Ribereau-Gayon, J., Peynaud, E., Sudraud, P., Ribereau-Gayon, P., 1972. Traité d'Enologie Sciences et Techniques du Vin, Tome 1, Dunod, Paris.

Salón, J.L., Chirivella, C., Castel, J.R., 2005. Response of Cv. Bobal to timing of deficit irrigation in Requena, spain: water relations, yield and wine quality. Am. J. Enol. Vitic. 56, 1-8.

Sanguankeo, P.P., Ramon, G.L., Malone, J., 2009. Impact of weed management practices on grapevine growth and yield components. Weed Sci. 57, 103-107.

Santos, T.P., Lopes, C.M., Rodrigues, M.L., Souza, C.R., Maroco, J.P., Pereira, J.S., Silva, J.R., Chaves, M.M., 2003. Partial rootzone drying: effects on growth and fruit quality of field-grown grapevines Vitisvinifera L. Funct. Plant Biol. 30, 663-671.

Santos, T.P., Lopes, C.M., Rodrigues, M.L., Souza, C.R., Silva, J.R., Maroco, J.P., Pereira, J.S., Chaves, M.M., 2005. Effects of partial root-zone drying irrigation on cluster microclimate and fruit composition of field-grown Castelão grapevines. Vitis 44, $117-125$.
Santos, T., Lopes, C.M., Rodrigues, M.L., Souza, C.R., Maroco, J., Pereira, J.S., Silva, J.R. Chaves, M.M., 2007. Effects of deficit irrigation treatments on cluster microclimate for improving fruit composition of 'Moscatel' field-grown grapevines. Sci. Hort. 112, 321-330.

Schultz, H.R., 2007. Climate change: implications and potential adaptation of vine growth and wine composition. In: Proceedings Congress on Climate and Viticulture, Centro Transferencia Agroalimentaria , Saragoza, pp. 151-155.

Skrotch, W., Shribbs, J.M., 1986. Orchard floor management: an overview. Hort. Sci. 21, 390-394.

Smart, R.E., Robinson, M., 1991. Sunlight Into Wine. A Handbook for Winegrape Canopy Management. Winetitles, Adelaide.

Spayd, S.E., Tarara, J.M., Mee, D.L., Ferguson, J.C., 2002. Separation of sunlight and temperature effects on the composition of Vitisvinifera cv. 'Merlot' berries. Am. J. Enol. Vitic. 53, 171-182.

Stoll, M., Loveys, B., Dry, P., 2000. Hormonal changes induced by partial rootzone drying of irrigated grapevine. J. Exp. Bot. 51, 1627-1634.

Streit, B., Rieger, S.B., Stamp, P., Richner, W., 2003. Weed populations in winter wheat as affected by crop sequence, intensity of tillage and time of herbicide application in a cool and humid climate. Weed Res. 43, 20-32.

Tesic, D., Keller, M., Hutton, R.J., 2007. Influence of vineyard floor management practices on grapevine vegetative growth, yield and fruit composition. Am. J. Enol. Vitic. 58, 1-11.

Van Leewen, C., Tregoat, O., Choné, X., Bois, B., Pernet, D., Gaudillère, J.P., 2009. Vine water status is a key factor in grape ripening and vintage quality for red Bordeaux wine. How can it be assessed for vineyard management purposes? J. Int. Sci. Vigne Vin. 43 (3), 121-134.

Wade, J., Holzapfel, B., Degaris, K., Williams, D., Keller, M., 2004. Nitrogen and water management strategies for wine-grape quality. Acta Hort. 640, 61-67.

Wample, R.L., Smithyman, R., 2002. Regulated deficit irrigation as a water management strategy in vitisvinifera production. In: FAO (Eds.), Deficit Irrigation Practices, Rome, pp. 89-100.

Williams, L.E., Matthews, M.A., 1990. Grapevine. In: Stewart, B.A., Nielsen, D.R.(Eds.) Irrigation of Agricultural Crops. Series of Agronomy, vol. 30. American Society of Agronomy, Madison, Wisconsin, USA, pp. 1019-1055. 